\title{
Liquidity and Asset Prices: How Strong are the Linkages? ${ }^{1}$
}

\author{
Christian Dreger \\ German Institute for Economic Research (DIW Berlin) \\ Mohrenstr. 58, D-10117 Berlin, Germany \\ Tel: +49-30-89789-231 E-mail: cdreger@diw.de \\ Jürgen Wolters \\ Freie Universität Berlin \\ Boltzmannstr. 20, D-14195 Berlin, Germany \\ Tel: +49 30 838-52014 E-mail: wolters@wiwiss.fu-berlin.de
}

\begin{abstract}
The appropriate design of monetary policy in integrated financial markets is one of the most challenging areas for central banks. One hot topic is whether the increase in liquidity has contributed to the formation of price bubbles in asset markets in the years preceding the financial crisis. If linkages are strong, the inclusion of asset prices in the monetary policy rule may limit speculative runs and negative spillovers to the real economy in the future. To examine the impacts of liquidity shocks on real share and house prices, VAR models are specified for the US and the euro area, as well as global VARs to control for international feedback. The analysis points to some impact of liquidity shocks on house prices, but the effect is restricted to the US. Stock market prices are not affected. Thus, the results suggest that the link between liquidity and asset prices is fragile and far from being obvious.
\end{abstract}

JEL Classifications: E44, G10, C32, C52

Keywords: Liquidity shocks, Asset prices, GVAR analysis, Monetary policy

\section{Introduction}

The appropriate design of monetary policy in integrated financial markets is one of the most challenging areas currently facing central banks; see for example De Santis, Favero and Roffia (2008). One important aspect is whether monetary policy should respond to asset price fluctuations, if they are driven by mass psychology mechanisms such as herding behaviour (Shiller, 2005). Non fundamental increases in asset prices can trigger inflationary pressures and cause an inefficient allocation of resources. They could generate overconsumption patterns because of perceived wealth effects, and capital overaccumulation due to lower costs of capital (Dupor and Conley, 2004). Bursting bubbles may lead to financial crises that are transmitted to the real economy and undermine the growth perspectives for some time, like the collapse of the new economy after the turn of the century and the recent subprime and financial crisis.

A pre-emptive reaction of monetary policy might help to limit the buildup of financial imbalances and the risks for a bust in the future. Therefore, some authors have recommended that

\footnotetext{
${ }^{1}$ The research leading to these results has received funding from the European Community's Seventh Framework Programme (FP7/2007-2013) under grant agreement number 217266. We would like to thank an anonymous referee and the participants of the Global Liquidity and Asset Prices session of the annual meeting of the Verein für Socialpolitik, Kiel 2010, for helpful comments and suggestions.
} 
central banks should lean against the wind, see for example Bordo and Jeanne (2002), Borio and White (2004) and Borio (2006). On the other hand, Bernanke and Gertler (2001) and Mishkin (2007) have stressed that rules that directly target asset prices can have undesirable side effects. In periods of rapid price increases in asset markets, a tighter monetary policy stance can lead to significant output losses. Thus, monetary policy should respond to asset prices only insofar as they affect inflation and output expectations.

Besides the difficulties that central banks are required to identify bubbles in the development of asset prices in real time, a leaning against the wind behaviour assumes a robust link between monetary policy and asset markets. In particular, liquidity shocks should have predictable consequences on asset prices. In order to explore the relationship, country individual and global VAR models are estimated for the US and the euro area. As a robustness check, asset prices are measured either by real share or real housing prices, respectively.

Generalized impulse response analysis and variance decomposition of forecast errors serve as the main tools of the analysis. The evidence shows that the impact of liquidity shocks on asset prices is far from being robust. While monetary policy does not affect share prices, it might have an impact on house prices, but this result is restricted to the US. Differences between the country individual and global VAR frameworks are not substantial in most cases, implying that the integration in financial markets does not have a huge impact on these results.

The rest of the paper is organized as follows. The main transmission channels between monetary policy and asset prices are reviewed together with the earlier empirical evidence in section 2. Section 3 discusses data properties and presents the results. Section 4 offers policy conclusions.

\section{Monetary Policy and Asset Prices}

Several arguments point to an impact of monetary policy on asset prices. A positive liquidity shock will affect the quantity and marginal utility of money holdings relative to other financial assets, consumption and capital goods. To restore equilibrium a rebalancing of the liquidity/asset ratio compatible with optimal portfolio allocation is required (Congdon, 2005). The adjustment process triggers higher asset demand and subsequent price increases, see Friedman (1988) and Meltzer (1995). According to Adrian and Shin (2008) this effect is amplified through a procyclical balance sheet management of the financial intermediaries. The leverage, defined as the ratio of total assets to equity is raised in asset price booms and reduced in downturns. The achievement of higher price stability might have reduced risk premia and asset price volatility, thereby creating excess credit pressures and additional leverage (see Borio and Lowe, 2002). Easily available credit, eventually caused by a global savings glut, led to low real interest rates that boosted asset demand, see Himmelberg, Mayer and Sinai (2005) and Taylor (2009). The presence of liquidity constraints can weaken these effects. Furthermore, the link between monetary policy and asset prices is not unidirectional. A reversed causation is justified from a money demand perspective. Higher asset prices increase demand for liquidity due to a rise in the net household wealth position. Greiber and Setzer (2007) and Dreger and Wolters (2009) have reported empirical evidence for this effect in the euro area.

Previous papers have explored the impact of monetary shocks on asset prices, but the results are far from being conclusive. Baks and Kramer (1999) stressed that a rise in global liquidity coincides with a decrease in real interest rates and an increase in stock market returns. Due to Roffia and Zaghini (2007), periods of strong monetary growth are likely to be followed by periods of high inflation, provided that money growth is accompanied by asset price inflation. A monetary expansion appears to be less harmful to overall inflation if asset prices do not accelerate. Adalid and Detken (2007) found that monetary policy and asset prices are associated over mechanically identified boom and bust cycles in asset markets. Shocks to real liquidity appear to be a major driver of real estate prices in boom episodes and have some explanatory power for the depth of post 
boom recessions. Belke, Orth and Setzer (2008) have emphasized that a global liquidity shock leads to a rise in consumer and global house prices, where the latter reaction is more pronounced. However, the results cannot be generalized, as there is no impact on share prices. Likewise, Rüffer and Stracca (2006) failed to detect any significant reaction of asset prices to liquidity shocks.

\section{Data Issues and Results}

According to Giuliodori (2005) and other authors, the linkages between liquidity shocks and asset prices are investigated by means of VAR models, as these tools are standard to analyse the interactions between the relevant variables. However, the findings at the individual country level might blur the effects actually at work. Liquidity shocks in one region can be absorbed by other regions due to integrated financial markets, see Giese and Tuxen (2007) and Assenmacher-Wesche and Gerlach (2008). To obtain robust evidence, both country individual and global VARs are specified. Differences in the results can provide a measure on the impact of financial market integration.

In a global VAR, the evolution of domestic variables can be driven by foreign series, as international linkages are taken into account, see Pesaran, Shuermann and Smith (2004) and Dées, Di Mauro, Pesaran and Smith (2007). Foreign variables refer to a weighted average of variables from other regions and can enter contemporaneously and with lags. Weights might be chosen, for example, with respect to GDP or trade shares. However, if only a few countries are involved, aggregation is not strictly required. A global VAR can be re-written as an ordinary VAR for all variables of the system, see the appendix. Therefore, different aggregation methods cannot affect the results. In the normal case, the individual VARs augmented with foreign variables are estimated and the global VAR is then obtained by solving for the contemporaneous explanatory variables from the individual estimates. As there are only two regions with five endogeneous variables, a sufficient number of degrees of freedom is available to estimate the VAR even without the restrictions normally imposed on GVAR models.

The individual country VARs are specified for the US and the euro area (initial member states) and comprise five variables: the nominal money stock as a liquidity measure (m), the nominal interest rate for financial assets with long periods to maturity (i), the price level (p), real income (y), and real asset prices (w), the latter proxied either as real share or housing prices. The global VAR is based on these ten variables, i.e. the same set of variables for both regions. In addition, the oil price enters as an exogeneous variable in all models. Generalized impulse responses and variance decompositions of forecast errors are employed to avoid problems related to the ordering of the variables (Pesaran and Shin, 1998).

The analysis is built on quarterly seasonally adjusted data ranging from 1985.1-2007.4, i.e. the endpoint of the sample is just before the economic downturn due to the financial crisis. Nominal monetary aggregates refer to end of period values for M2 in the US and M3 in the euro area. Nominal income is GDP at current prices. Asset prices are share prices on the stock market or price indexes for new houses. Series in real terms are obtained by deflating the respective nominal measure with the GDP deflator $(2000=100)$. The long term interest rate is the yield for government bonds with 10 years to maturity. The main data source is the World Market Monitor provided by Global Insight. GDP figures for the pre-euro area period are from Brand and Cassola (2004). All series are expressed in logarithms, except of interest rates.

The VAR models are specified for the series defined in their levels. For integrated variables this leads to consistent estimates, as cointegrating relationships are implicitly embedded (see Sims, Stock and Watson, 1990). The lag length is determined by the Schwarz criterion, as this measure is the most accurate one for integrated data and the relevant sample size (Ivanov and Kilian, 2005). This parameter is equal to 2 in the country models and 1 in the global VAR environment. All specifications are estimated with a linear time trend. As the impulse responses are estimated rather imprecisely, one standard error confidence bands obtained by Monte Carlo methods are preferred instead of the conventional significance levels, as recommended by Sims and Zha (1999). 


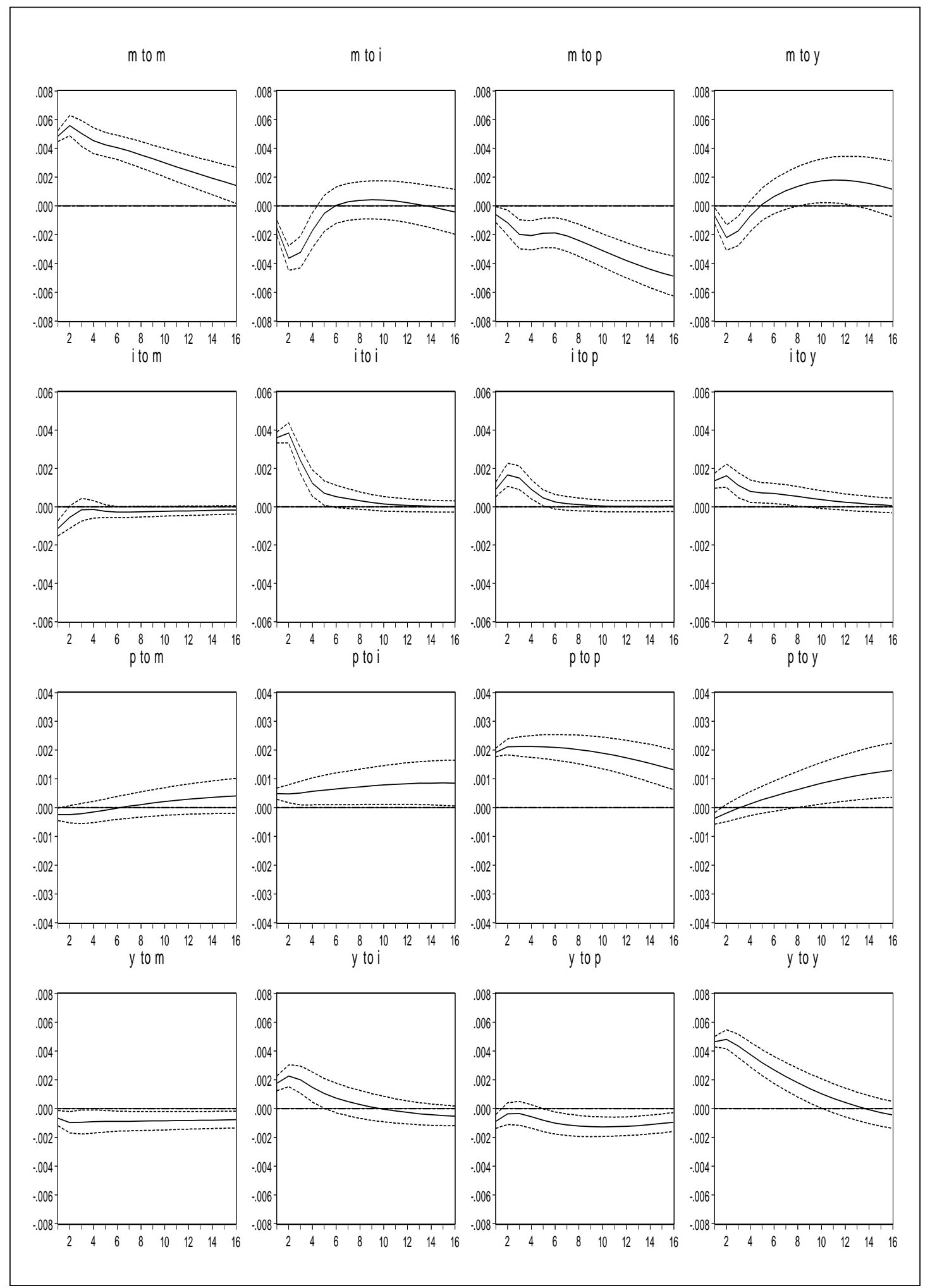

Figure 1. Impulse response analysis, benchmark model: United States

Note: Generalized impulse responses. Dashed lines denote one standard error band. 


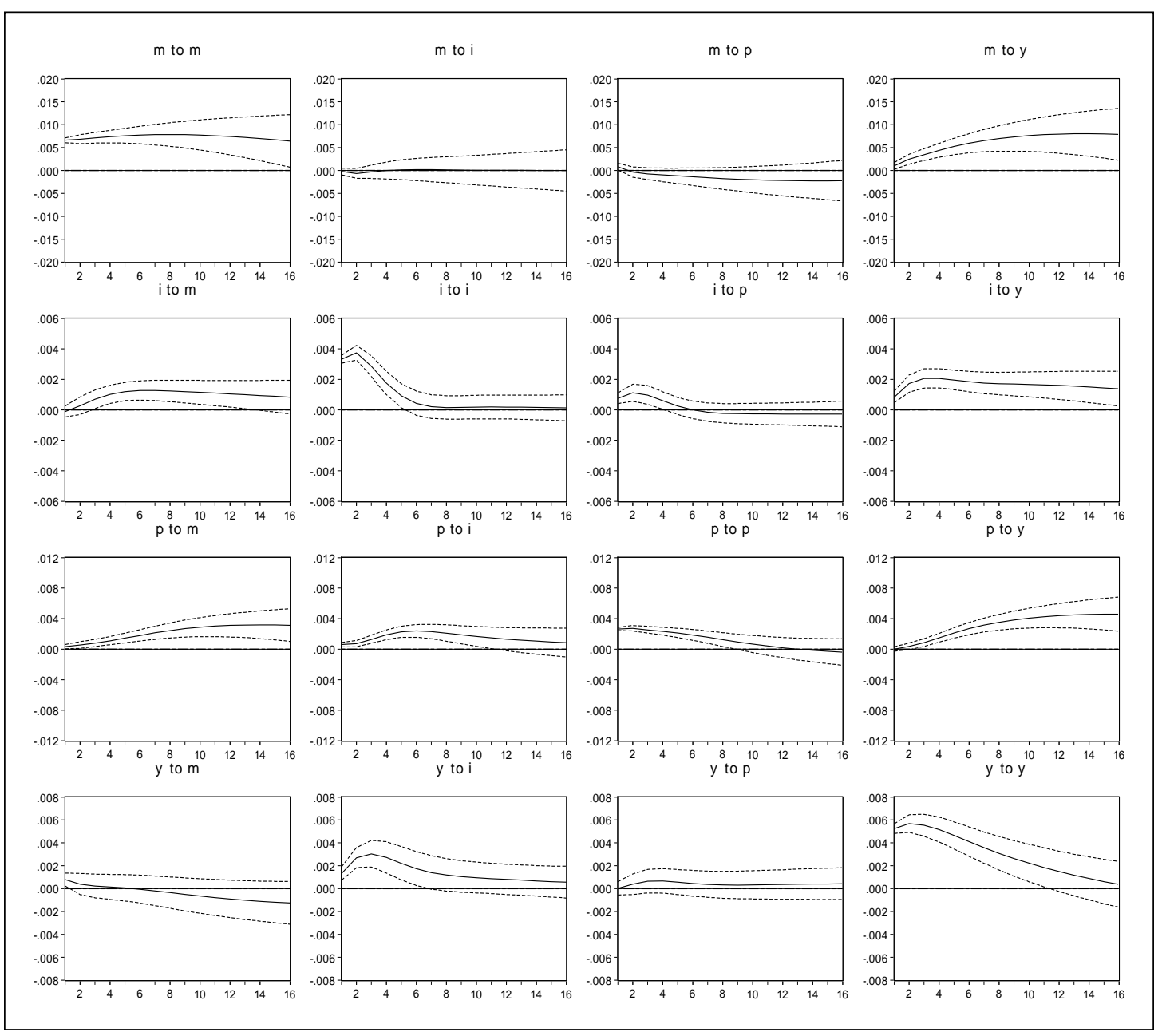

Figure 1. (cont'd): Euro area

Note: Generalized impulse responses. Dashed lines denote one standard error band.

First, individual country models are estimated without asset prices, see Figure 1. These models serve as a benchmark for the further analysis. Most responses are in line with theoretical reasoning. In line with standard models of money demand, a positive income shock raises liquidity in the euro area in the short and long run. In the US this effect holds in the long run. Furthermore, prices and long term interest rates are expected to increase due to higher inflation pressure. A shock in liquidity leads to an interest rate cut in the US, but to a rise in the euro area. Nonetheless, the latter reaction might be plausible, because prices also increase, and inflation expectations are embedded in the nominal interest rate. By the same sort of argument, a positive response of prices and income to higher interest rates can be justified. In the US, money declines after a positive price shock. This can indicate portfolio shifts from liquid to real assets. Overall, the benchmark does not produce implausible results and should be appropriate to examine the linkages between liquidity and wealth.

Figure 2 displays the interactions between liquidity and asset prices, when the latter is proxied by share prices, while figure 3 has the same information for the house price alternative. The two columns on the left are obtained from the country models, and the columns on the right hand side are from the global VAR. In order to safe space, only these interactions are exhibited. The entire set of impulse responses is available from the authors upon request. 

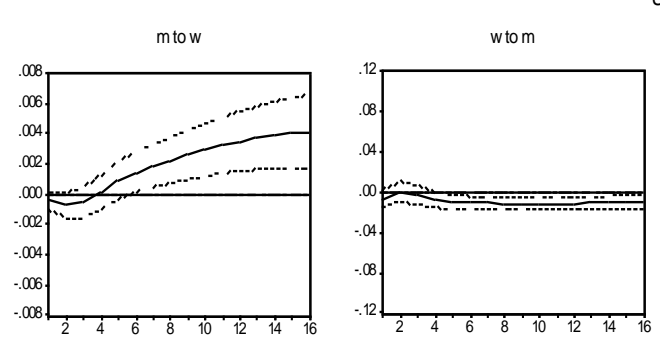

United States
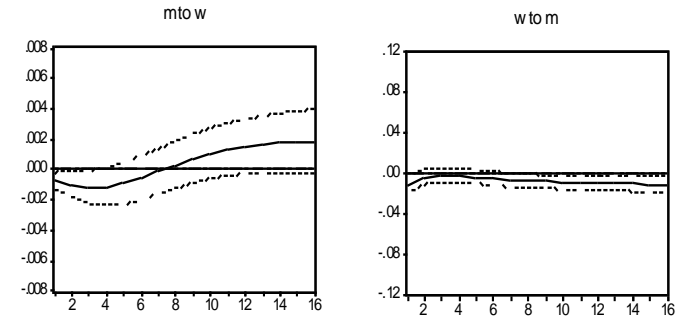

Euro area
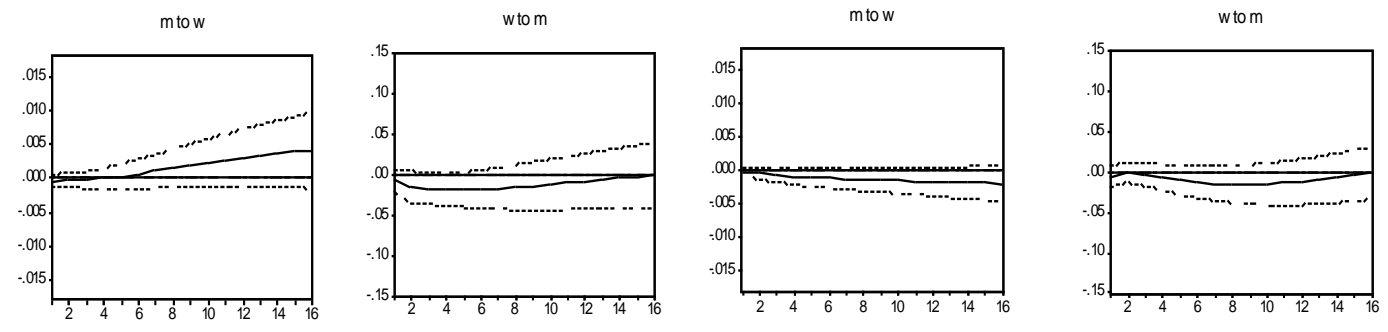

Figure 2. Impulse response analysis, share price model

Note: Generalized impulse responses. Dashed lines denote one standard error band.

First and second column country model, third and fourth column global model

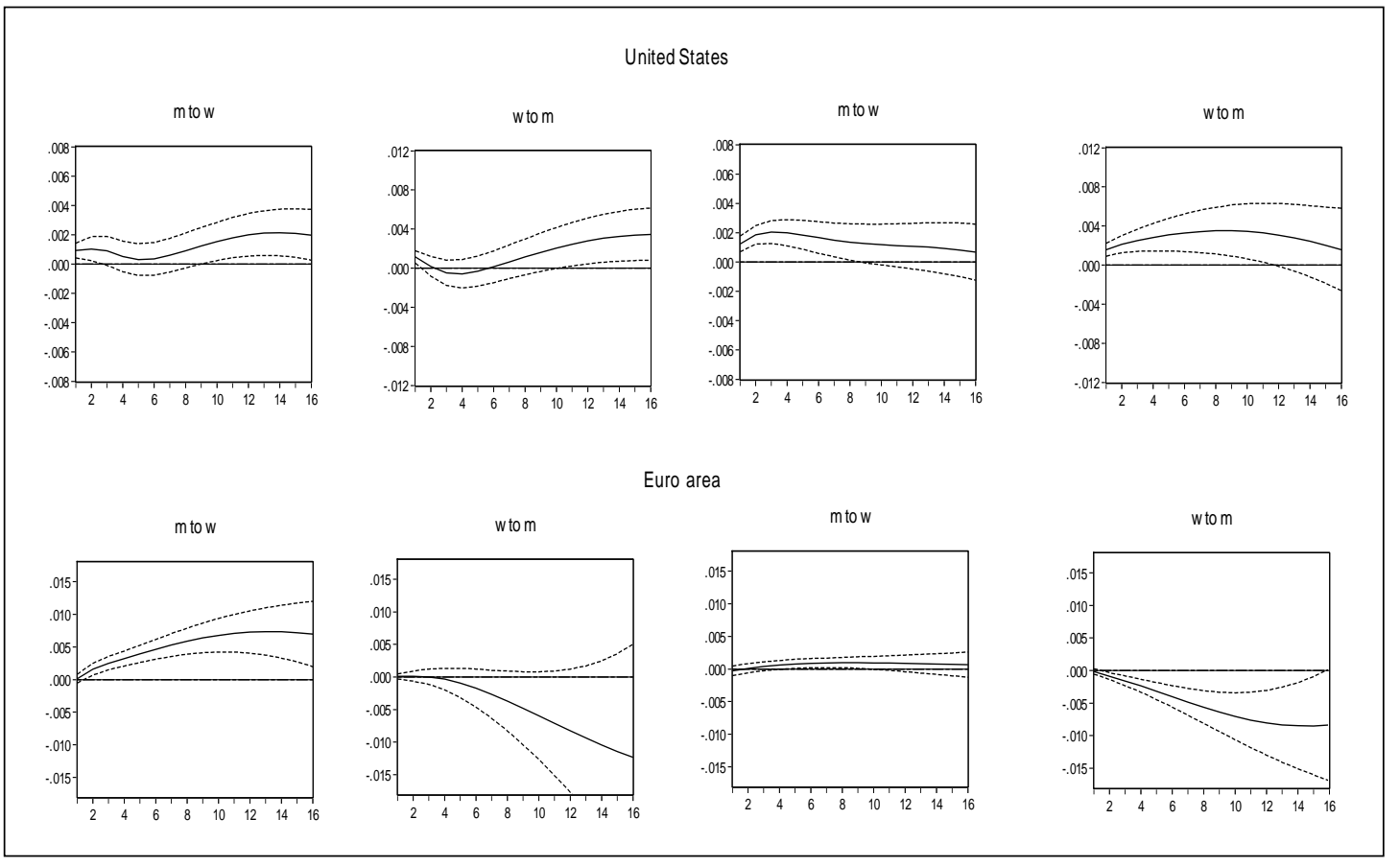

Figure 3. Impulse responses, house price model

Note: Generalized impulse responses. Dashed lines denote one standard error band.

First and second column country model, third and fourth column global model 
The evidence is broadly similar for the individual country and the global VAR, i.e. does not depend heavily on the degree of international spillovers. 2 According to Figure 2, a significant long run effect of liquidity to share prices is observed for the US VAR. However, this effect is not robust: it vanishes, if international spillovers are taken into account. Reversed effects are not existent. As a striking feature, house prices react to liquidity shocks. However, a positive reaction is limited to the US (Figure 3). For the euro area, the multipliers are not significant, and become even negative in the global model. This result might be linked to institutional differences in the mortgage markets. The reversed channel, i.e. rising liquidity as a response to an increase in wealth seems to be more relevant and could be interpreted as an indication for the presence of wealth effects on money demand. In any case, these results cast serious doubts on the existence of a strong link running from liquidity to asset prices.

The variance decomposition exercise is broadly in line with the impulse responses, see Tables 1 and 2. According to some specifications, the variance of forecast errors in asset prices at longer forecasting horizons can be traced to a large extent to liquidity shocks, see the share price model in the US and the house price model for the euro area. However, this evidence is not robust. In particular, it cannot be replicated in the global VAR environment. In this sense, these results are blurred due to the exclusion of international spillovers.

Table 1. Forecast error variance decomposition of liquidity shock

(1) Share price model

\begin{tabular}{|r|c|c|c|c|c|c|c|c|}
\hline & \multicolumn{4}{|c|}{ Country VAR } & \multicolumn{4}{c|}{ Global VAR } \\
\hline & \multicolumn{2}{|c|}{ United States } & \multicolumn{2}{c|}{ Euro area } & \multicolumn{2}{c|}{ United States } & \multicolumn{2}{c|}{ Euro area } \\
\hline Steps & $m$ & $w$ & $m$ & $w$ & $m$ & $w$ & $m$ & $w$ \\
\hline 4 & 87.8 & 0.3 & 88.6 & 0.0 & 54.2 & 0.1 & 87.6 & 0.8 \\
\hline 8 & 79.5 & 6.8 & 74.8 & 0.9 & 47.5 & 0.3 & 63.3 & 2.6 \\
\hline 16 & 47.8 & 22.5 & 58.5 & 6.0 & 32.3 & 3.3 & 31.5 & 5.6 \\
\hline
\end{tabular}

(2) House price model

\begin{tabular}{|r|c|c|c|c|c|c|c|c|}
\hline & \multicolumn{4}{|c|}{ Country VAR } & \multicolumn{4}{c|}{ Global VAR } \\
\hline & \multicolumn{2}{|c|}{ United States } & \multicolumn{2}{c|}{ Euro area } & \multicolumn{2}{c|}{ United States } & \multicolumn{2}{c|}{ Euro area } \\
\hline Steps & $m$ & $w$ & $m$ & $w$ & $m$ & $w$ & $m$ & $w$ \\
\hline 4 & 81.6 & 2.6 & 85.1 & 8.1 & 48.6 & 1.0 & 90.4 & 0.9 \\
\hline 8 & 71.9 & 2.1 & 51.2 & 42.9 & 40.4 & 1.8 & 66.8 & 8.0 \\
\hline 16 & 41.8 & 2.2 & 18.8 & 75.9 & 32.2 & 1.7 & 64.9 & 9.2 \\
\hline
\end{tabular}

Note: Entries show the percentage share of the forecast error variance of liquidity or asset prices,

respectively, that are related to liquidity shocks.

\footnotetext{
${ }^{2}$ If short term interest rates are used instead of the money stock, the differences between the results are not substantial.
} 
Table 2: Forecast error variance decomposition of wealth shock

(1) Share price model

\begin{tabular}{|r|c|c|c|c|c|c|c|c|}
\hline & \multicolumn{4}{|c|}{ Country VAR } & \multicolumn{4}{c|}{ Global VAR } \\
\hline & \multicolumn{2}{|c|}{ United States } & \multicolumn{2}{c|}{ Euro area } & \multicolumn{2}{c|}{ United States } & \multicolumn{2}{c|}{ Euro area } \\
\hline Steps & $m$ & $w$ & $m$ & $w$ & $m$ & $w$ & $m$ & $w$ \\
\hline 4 & 1.2 & 90.0 & 2.1 & 92.0 & 4.1 & 37.2 & 0.3 & 78.6 \\
\hline 8 & 4.5 & 83.7 & 3.4 & 85.9 & 14.4 & 30.7 & 2.1 & 59.5 \\
\hline 16 & 10.5 & 76.9 & 3.5 & 70.8 & 19.6 & 23.9 & 3.6 & 46.2 \\
\hline
\end{tabular}

(2) House price model

\begin{tabular}{|r|c|c|c|c|c|c|c|c|}
\hline & \multicolumn{4}{|c|}{ Country VAR } & \multicolumn{4}{c|}{ Global VAR } \\
\hline & \multicolumn{2}{|c|}{ United States } & \multicolumn{2}{c|}{ Euro area } & \multicolumn{2}{c|}{ United States } & \multicolumn{2}{c|}{ Euro area } \\
\hline Steps & $m$ & $w$ & $m$ & $w$ & $m$ & $w$ & $m$ & $w$ \\
\hline 4 & 0.8 & 82.9 & 0.1 & 91.5 & 4.5 & 31.8 & 13.0 & 52.8 \\
\hline 8 & 0.7 & 75.1 & 2.8 & 89.9 & 5.8 & 16.4 & 35.2 & 29.8 \\
\hline 16 & 6.3 & 40.1 & 19.0 & 71.5 & 7.9 & 9.4 & 59.1 & 13.7 \\
\hline
\end{tabular}

Note: Entries show the percentage share of the forecast error variance of liquidity or asset prices, respectively, that are related to shocks in asset prices.

\section{Conclusions}

The appropriate design of monetary policy in integrated financial markets is one of the most challenging areas for central banks. One hot topic is whether the rise in liquidity in recent years has contributed to the formation of price bubbles in asset markets. If strong linkages exist, the inclusion of asset prices in the monetary policy rule might be an appropriate strategy to limit speculative runs and negative spillovers to the real economy in the future. In this paper the impacts of liquidity shocks on real share and house prices are investigated for the period from 1985.1 to 2007.4, i.e. the endpoint of the sample is just before the economic downturn due to the financial crisis. Standard VAR models are specified for the US and the euro area. To control for international dependencies, global VARs are also considered. Differences in the results can provide a measure on the impact of financial market integration. The specifications point to some impact of liquidity shocks on house prices in the US, while share prices are not affected. For the euro area, a significant relationship cannot be established. Thus, the results suggest that the link between liquidity and asset prices is fragile and far from being obvious.

\section{References}

[1] Adalid, R., and Detken, C. Liquidity shocks and asset price boom/bust cycles. ECB Working Paper (2007): 732, European Central Bank, Frankfurt.

[2] Adrian, T., and Shin, HS. Liquidity, monetary policy and financial cycles, Current Issues in Economics and Finance 14, Federal Reserve Bank of New York (2008). 
[3] Assenmacher-Wesche, K., and Gerlach, S. Financial structure and the impact of monetary policy on asset prices. Swiss National Bank Working Paper (2008): 16.

[4] Baks, K., and Kramer, C. Global liquidity and asset prices: Measurement, implications and spillovers. IMF Working Paper (1999): 99/168.

[5] Belke, A., Orth, W., and Setzer, R. Sowing the seeds of the subprime crisis - Does global liquidity matter for housing and other asset prices. International economics and economic policy 5 (2008): 403-424.

[6] Bernanke, B., and Gertler, M. Should central banks respond to movements in asset prices? American Economic Review Papers and Proceedings 91 (2001): 253-257.

[7] Bordo, MD., and Jeanne, O. (2002): Boom-busts in asset prices, economic inst Borio C (2006): Monetary and financial stability: Here to stay? Journal of Banking and Finance $30,3407-14$.

[8] Borio, C., and Lowe, P. Asset prices, financial and monetary stability: Exploring the nexus, Bank for International Settlements Working Paper 114 (2002).

[9] Borio, C. and White, W. Whither monetary and financial stability? The implications of evolving policy regimes. BIS Working Paper 147 (2004).

[10] Brand, C., and Cassola, N. A money demand system for euro area M3. Applied Economics 8 (2004): 817-838.

[11] Congdon, T. Money and asset prices in boom and bust. Institute of Economic Affairs, IEA Hobart Paper 153 (2005).

[12] De Santis, RA, Favero, CA., and Roffia, B. Euro area money demand and international portfolio allocation: A contribution to assessing risks to price stability. ECB Discussion Paper 926 (2008).

[13] Dées. S., Di Mauro, F., Pesaran, MH., and Smith, V. Exploring the international linkages of the euro area. A global VAR analysis. Journal of Applied Econometrics 22 (2007): 1-38.

[14] Dreger, C., and Wolters, J. Money velocity and asset prices in the euro area. Empirica 36 (2009): 51-63.

[15] Dupor, B., and Conley, T. The fed response to equity prices and inflation. American Economic Review. Papers and Proceedings 94 (2004): 24-28.

[16] Friedman, M. Money and the stock market. Journal of Political Economy 96 (1988): 221-245.

[17] Giese, JV., and Tuxen, CK. Global liquidity and asset prices in a cointegrated VAR, manuscript (2007).

[18] Greiber, C. and Setzer, R. Money and housing: Evidence for the euro area and the US. Deutsche Bundesbank, Research Center, Discussion Paper Series 1 (2007): Economics.

[19] Giuliodori, M. The role of house prices in the monetary transmission mechanism across European countries. Scottish Journal of Political Economy 52 (2005): 519-543. 
[20] Himmelberg, C., Mayer, C., and Sinai, T. Assessing high house prices: Bubbles, fundamentals and misperceptions. Journal of Economic Perspectives 19 (2005): 67-92.

[21] Ivanov, V., and Kilian, L. A practitioner's guide to lag order selection for VAR impulse response analysis. Studies in Nonlinear Dynamics and Econometrics 9 (2005): Issue 1.

[22] Meltzer, A. Monetary, credit and (other) transmission processes: A monetarist perspective. Journal of Economic Perspectives 9 (1995): 49-72.

[23] Mishkin, FS. Housing and the monetary transmission mechanism. Paper presented at the Federal Reserve Bank of Kansas City 31st Economic Policy Symposium, Jackson Hole (2007): Wyoming.

[24] Pesaran, MH., and Shin, Y. Generalized impulse response analysis in linear multivariate models, Economics Letters 58 (1998): 17-29.

[25] Pesaran, MH., Shuermann,, T. and Smith, V. Modelling regional interdependencies using a global error correcting macroeconometric model, Journal of Business and Economic Statistics 22 (2004): 129-162.

[26] Roffia, B., and Zaghini, A. Excess money growth and inflation dynamics. International Finance 10 (2007): 241-280.

[27] Rüffer, R., and Stracca, L. What is global excess liquidity, and does it matter? ECB Working Paper 696, (2006): European Central Bank, Frankfurt.

[28] Shiller,R. Irrational exuberance, Princeton University Press (2005): New Jersey.

[29] Sims, CA., Stock, JH., and Watson, MW. Inference in linear time series models with some unit roots. Econometrica 58 (1990): 113-144.

[30] Sims, CA., and Zha, T. Error bands for impulse responses. Econometrica 67, (1999), 1113-1156.

[31] Taylor, JB. Getting off track: How government actions and interventions caused, prolonged, and worsened the financial crisis, Hoover Institution Press (2009). 